\title{
Preparation and Characterization of Starch Grafted with Toluene \\ Poly(propylene oxide) Diisocyanate
}

\author{
D.C. Dragunski, A. Pawlicka* \\ Instituto de Química de São Carlos, Universidade de São Paulo, \\ 13560-970 São Carlos - SP, Brazil
}

Received: November 11, 2000; Revised: April 20, 2001

\begin{abstract}
Amylopectin-rich starch samples (Amidex 4001 Corn Products Brasil Ingredientes Industriais Ltda.) were grafted with polyethers with the purpose of obtaining new materials for application as solid polymeric electrolytes. Grafting reaction was performed by the addition of starch dissolved in DMSO to toluene poly(propylene oxide) diisocyanate (Resibras) dissolved in the same solvent. This reaction produced a film with good mechanical properties. The film samples were characterized by ${ }^{13}$ C-NMR, FTIR, DSC, X-Ray and SEM. The FTIR spectrum shows a sharp NH band and a very small urethane band. The ${ }^{13} \mathrm{C}-\mathrm{NMR}$ spectrum revealed a peak at $20 \mathrm{ppm}$, that can be attributed to the $\mathrm{CH}_{3}$ of the polyether chain, and two small peaks at 117 and $140 \mathrm{ppm}$, attributed to the aromatic ring. The X-ray diffractograms also indicated that after the grafting reaction, the samples of amylopectin-rich starch are more amorphous. Moreover, the glass transition temperature $(\mathrm{Tg})$ dropped from $50{ }^{\circ} \mathrm{C}$ to $-11^{\circ} \mathrm{C}$. These results indicate formation of grafted products and the low $\mathrm{Tg}$ of the samples suggests that polyether-grafted starch is a good candidate to obtain solid polymeric electrolytes.
\end{abstract}

Keywords: starch, grafting, solid polymeric electrolytes

\section{Introduction}

The development of new solid materials for application as electrolytes allows for the creation of modern energy generation and storage systems. Among these materials, solid polymeric electrolytes, usually elastomers containing lithium salts, offer a promising alternative to replace the liquid electrolytes and inorganic crystals used in batteries, sensors and electrochromic devices ${ }^{1}$.

Several types of solid electrolytes are being investigated. The most studied of these is poly(ethylene oxide) (PEO), which has lithium salt dissolving properties ${ }^{2}$. However, its tendency to crystallization reduces its ionic conductivity at room temperature, limiting its possible application as a solid polymeric electrolyte ${ }^{3}$. In order to take advantage of the excellent solubilization properties of these salts and simultaneously reduce the system's crystallinity, $\mathrm{PEO}$ can be modified by $\mathrm{Al}_{2} \mathrm{O}_{3}$ addition, resulting in blends ${ }^{4}$, co-polymerizations ${ }^{5}$ or grafting reactions with other polymers containing metals such as $\mathrm{Si}$ or totally organic polymers ${ }^{5,7,8}$. The last one include natural polymers such as polysaccharides, the principal ones being cellulose $^{9}$, quitosane ${ }^{10}$ and $\operatorname{starch}^{11}$.

Some polysaccharides and their derivatives are processable in the form of films, e.g., starch, hydroxyethyl cellulose (HEC). Thus, the films obtained from this polymer have good mechanical properties, besides being economically viable materials owing to both their easy availability in nature and their renewability ${ }^{12}$.

Similarly to HEC and hydroxypropyl cellulose $(\mathrm{HPC})^{13}$, starch can be modified by grafting reactions. The introduction of ramifications in the polymer chain can produce marked differences in its chemical and physicochemical behavior. Grafted products can be obtained by different chemical processes (radical or ionic), through reactions of substitution or addition ${ }^{14}$.

The main objective of this work, therefore, is to discuss the preparation and characterization of starch films grafted with toluene poly(propylene oxide) diisocyanate for potential application as solid polymeric electrolytes. 


\section{Experimental}

The amylopectin-rich starch samples (Amidex 4001 Corn Products Brasil Ingredientes Industriais Ltda.) were characterized by infrared spectroscopy (FTIR), nuclear magnetic resonance ( $\left.{ }^{1} \mathrm{H}-\mathrm{NMR}\right), \mathrm{X}$-ray diffraction (XRD), differential scanning calorimetry (DSC) and the film samples visualized by scanning electron microscopy (SEM).

The FTIR spectra of the samples of dry amylopectin, pressed into pellets with $\mathrm{KBr}$ (proportion 1:100 in weight), were obtained with a BOMEM model MB-102 spectrometer.

The ${ }^{1} \mathrm{H}-\mathrm{NMR}$ spectra of the starch samples $(3 \% \mathrm{w} / \mathrm{v}$ solution in deutered DMSO) were obtained using a BRUCKER AC200 (200 MHz) spectrometer.

The CP/MAS ${ }^{13} \mathrm{C}-\mathrm{NMR}$ spectra were obtained with a Varian Unity 400 spectrometer $(100,58 \mathrm{MHz})$ (Embrapa São Carlos, SP). The references used were tetramethylsilane and hexamethylbenzene as secondary reference (132,3 ppm).

The differential scanning calorimetry (DSC) analyses were performed using a SHIMADZU DSC-50 equipment, in a dynamic nitrogen atmosphere $(20 \mathrm{~mL} / \mathrm{min}$ flow $)$ and a heating rate of $10^{\circ} \mathrm{C} / \mathrm{min}$.

The X-ray analyses were obtained with an Carl Zeiss Jena URD-6 diffractometer with $\mathrm{CuK}$ irradiation $(\lambda=1540 \AA)$, and the micrographs were obtained with a ZEISS-LEICA 400 scanning electron microscope.

The toluene poly(propylene oxide) diisocyanate (Resibras) was characterized by FTIR and ${ }^{1} \mathrm{H}-\mathrm{NMR}$, using the same procedure described above for amylopectin.

The grafting reactions were performed by mixing an amylopectin solution $(0,05 \mathrm{~g}) / \mathrm{DMSO}(5 \mathrm{~mL})$ with a solution of diisocyanate $(0,78 \mathrm{~g}) / \mathrm{DMSO}(10 \mathrm{~mL})$ in a glove box under dry $\mathrm{N}_{2}$ atmosphere. The films were molded on a teflon plate and, left to rest for 48 hours, oven dried at $50{ }^{\circ} \mathrm{C}$ under vacuum, and then characterized by FTIR, NMR, $\mathrm{X}$-ray and SEM.

\section{Results and Discussions}

Figure 1 presents the infrared spectra of amylopectinrich starch and toluene poly(propylene oxide) diisocyanate. The wide band observed at $3348 \mathrm{~cm}^{-1}$ can be attributed to the $\mathrm{O}-\mathrm{H}$ stretching of the amylopectin and its width was ascribed to the formation of inter and intramolecular hydrogen bonds. The bands at 2935 and $2887 \mathrm{~cm}^{-1}$ were attributed to the asymmetric stretching of $\mathrm{C}-\mathrm{H}$, while the band at $1656 \mathrm{~cm}^{-1}$ was ascribed to adsorbed water and the bands at 1421 and at $1357 \mathrm{~cm}^{-1}$ to the angular deformation of C-H. The C-O ether bond shows stretching at $1156 \mathrm{~cm}^{-1}$ while the $\mathrm{C}-\mathrm{O}$ alcohol bond shows stretching at $1015 \mathrm{~cm}^{-1}$. Several main diisocyanate absorption bands were found, as follows: the band at $2260 \mathrm{~cm}^{-1}$ represents stretching of the $\mathrm{NCO}$ group; the low intensity bands at 1600 and $3400 \mathrm{~cm}^{-1}$

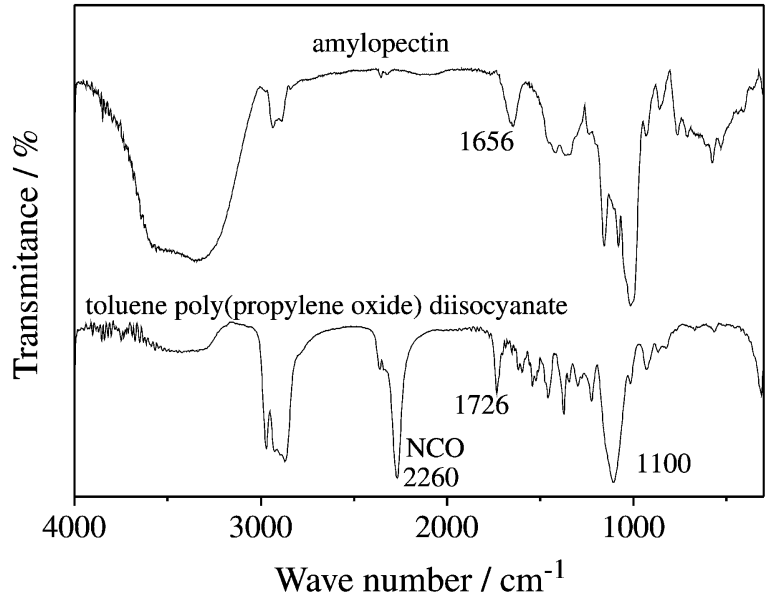

Figure 1. FTIR spectra of the amylopectin-rich starch and toluene poly(propylene oxide) diisocyanate.

were probably caused by vibrations of the $\mathrm{NH}$ bonds; the band at $1726 \mathrm{~cm}^{-1}$ represents stretching of the $\mathrm{C}=\mathrm{O}$ group; the one at $1100 \mathrm{~cm}^{-1}$ was caused by stretching of the $\mathrm{C}-\mathrm{O}$ group; the band at $2870 \mathrm{~cm}^{-1}$ represents stretching of the $\mathrm{C}-\mathrm{H}$ group; the one at $2970 \mathrm{~cm}^{-1}$ was caused by stretching of the $\mathrm{C}-\mathrm{H}\left(\mathrm{CH}_{3}\right)$ group; the band at $1370 \mathrm{~cm}^{-1}$ represents deformation of the $\mathrm{C}-\mathrm{H}$ bond; and finally, the bands at 1537 and $1450 \mathrm{~cm}^{-1}$ probably represent a three-substituted benzene ring ${ }^{15}$.

Figure 2 shows the ${ }^{1} \mathrm{H}-\mathrm{NMR}$ amylopectin spectrum while Fig. 3 presents that of the diisocyanate. Characteristic amylopectin peaks were found at $3.3 \mathrm{ppm}$, which was attributed to the hydrogens linked to the $\mathrm{C}_{6}$ carbon of $\mathrm{CH}_{2}-\mathrm{O}$ and $\mathrm{CH}_{2}-\mathrm{OH}$; at 3.6 ppm, attributed to the hydrogens linked to the $\mathrm{C}_{1}$ and $\mathrm{C}_{4}$ carbons of $\mathrm{CH}-\mathrm{O}$, at $3.9 \mathrm{ppm}$, attributed to the hydrogens linked to the $\mathrm{C}_{2}, \mathrm{C}_{3}$ and $\mathrm{C}_{5}$ carbons of $\mathrm{CH}-\mathrm{OH}$; and at $5.0 \mathrm{ppm}$, attributed to the hydrogens of the R-OH hydroxyl groups. This peak at $5.0 \mathrm{ppm}$ is slightly larger because of the presence of hydrogen bonds. Characteristic diisocyanate peaks were found at $1.05 \mathrm{ppm}$, which was attributed to the $\mathrm{CH}_{3}$ of the poly(propylene oxide) chain; at $1.99 \mathrm{ppm}$, ascribed to the toluene's $\mathrm{CH}_{3}$; at $2.21 \mathrm{ppm}$, attributed to the $\mathrm{CH}_{2}$ of the poly(propylene oxide) chain of $\mathrm{CH}_{2}-\mathrm{C}(=\mathrm{O}) \mathrm{N}$; and at $3.45 \mathrm{ppm}$, ascribed to $\mathrm{CH}_{2}$ and $\mathrm{CH}$ linked to oxygen. This peak is wider due to the very close chemical shift of these two hydrogens. Additional diisocyanate peaks were also present at 4.2 ppm, referring to $\mathrm{CH}$ linked to the $\mathrm{CH}-\mathrm{O}-\mathrm{CH}$ of the poly(propylene oxide) terminal group; at $5.0 \mathrm{ppm}$, for the hydrogen of the NH urethane bond; and at $7.2 \mathrm{ppm}$, which was attributed to the hydrogens of three-substituted benzene ring. The peak at $2.5 \mathrm{ppm}$ was attributed to the DMSO hydrogens ${ }^{15}$.

After the grafting reaction of starch with toluene poly(propylene oxide) diisocyanate, the FTIR spectrum 


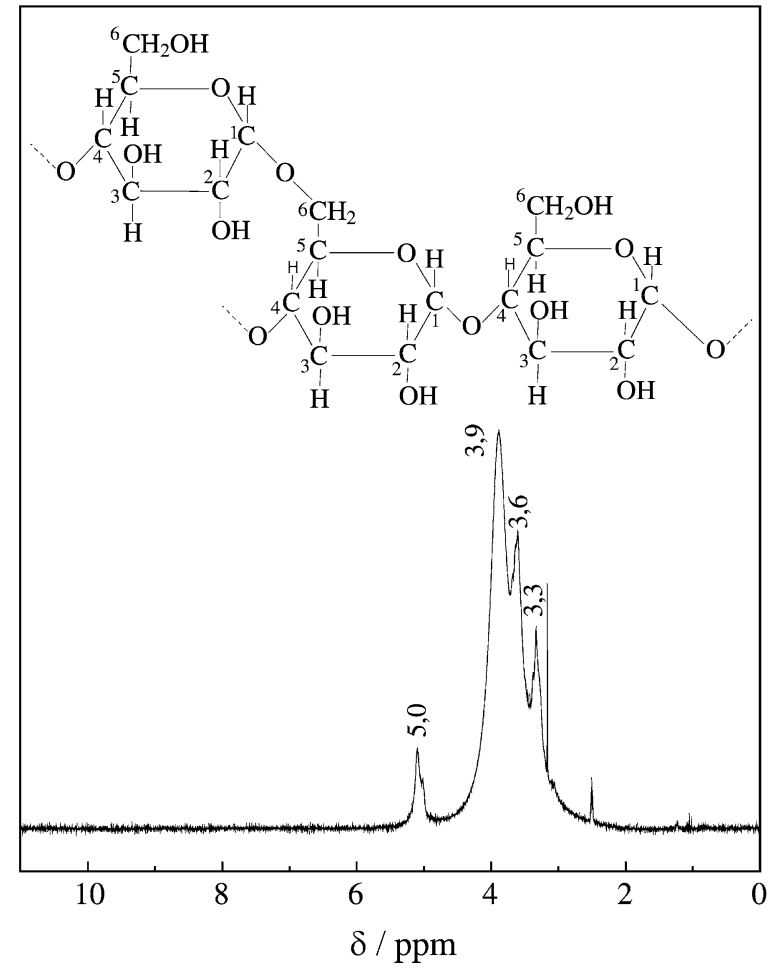

Figure 2. ${ }^{1} \mathrm{H}-\mathrm{NMR}$ spectrum of the amylopectin-rich starch.

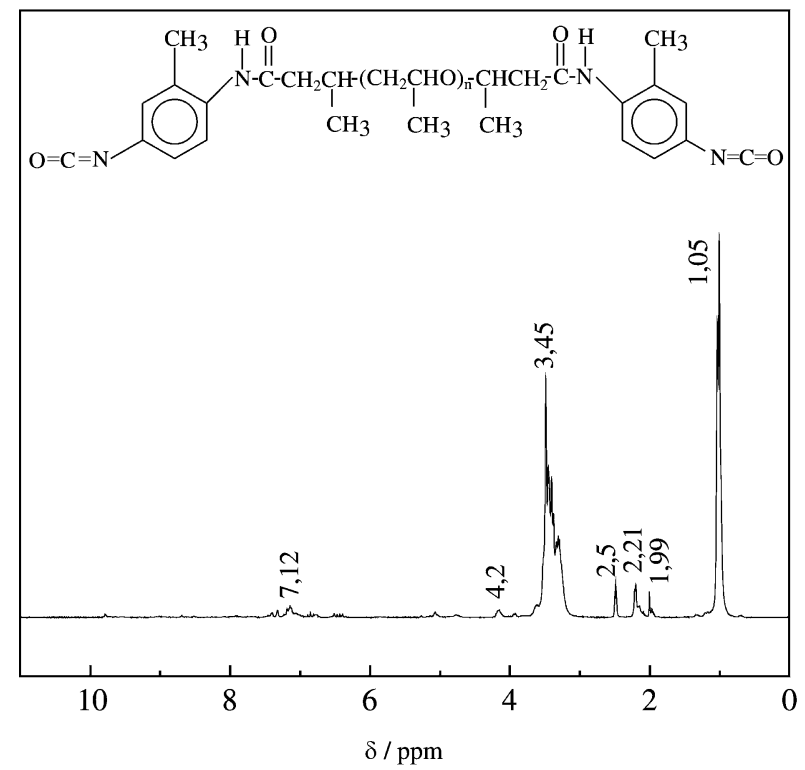

Figure 3. ${ }^{1} \mathrm{H}-\mathrm{NMR}$ spectrum of toluene poly(propylene oxide) diisocyanate.

(Fig. 4) shoved that the band attributed to the NCO group $\left(2260 \mathrm{~cm}^{-1}\right)$ disappeared and that a marked narrowing of another band at $3422 \mathrm{~cm}^{-1}$ occurred, which may be attributed to the formation of new $\mathrm{NH}$ bonds. In addition, a new urethane band was observed at approximately $1730 \mathrm{~cm}^{-1}$.

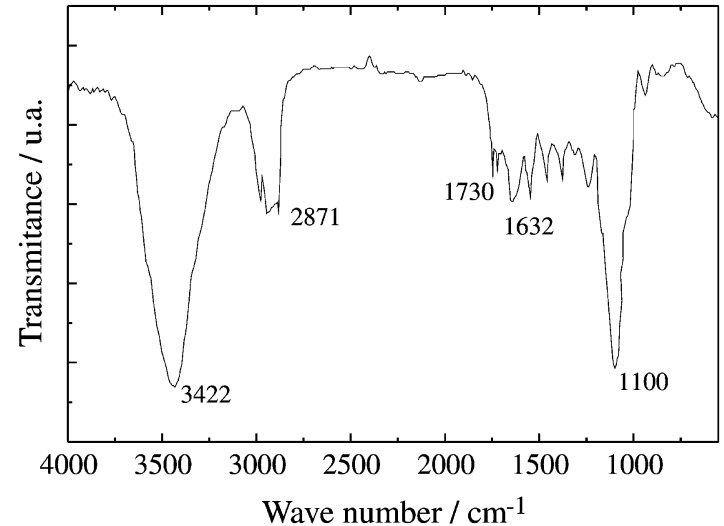

Figure 4. FTIR of the amylopectin-rich stanch grafted with toluene poly(propylene oxide) diisocyanate.

Figure 5 shows the ${ }^{13} \mathrm{C}$ RMN CP/MAS spectrum of amylopectin and grafted amylopectin. The peak at $64 \mathrm{ppm}$ can be attributed to $\mathrm{C}_{6}$ carbon; the one at 74 to the $\mathrm{C}_{2}, \mathrm{C}_{3}$, $\mathrm{C}_{4}$ and $\mathrm{C}_{5}$ carbons; and the peak at $103 \mathrm{ppm}$ to the $\mathrm{C}_{1}$ carbon. The grafted amylopectin showed peaks appearing at $20 \mathrm{ppm}$, attributed to the $\mathrm{CH}_{3}$ of the poly(propylene oxide) chain; at $67 \mathrm{ppm}$, produced by the $\mathrm{CH}_{2}-\mathrm{O}$; at 117 and at $140 \mathrm{ppm}$, which refer to the aromatic ring; and at $160 \mathrm{ppm}$, attributed to the urethane bond. A decrease was also observed in the intensity of the $\mathrm{C}_{6}$ peak, as well as a separation and displacement of the peaks attributed to the $\mathrm{C}_{2}, \mathrm{C}_{3}, \mathrm{C}_{4}$ and $\mathrm{C}_{5}$ carbons. These results suggest the formation of grafted amylopectin ${ }^{15}$.

The X-ray diffraction analysis (Fig. 6) also revealed a change in the structure of the amylopectin in relation to the amylopectin grafted with diisocyanate. The diffractograms of the amylopectin used for grafting presented three distinct peaks for the Bragg angles of 15, 18 and 23 degrees. This result is characteristic of cereal starch crystals, in this case corn; these crystals are known as A type ${ }^{16}$. The characteristic amylopectin peaks disappeared after the grafting reaction, indicating a predominantly amorphous state. This

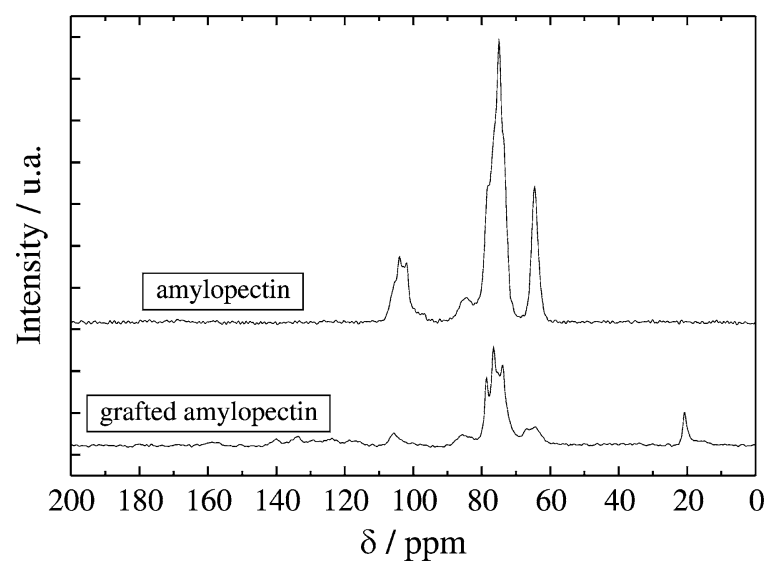

Figure 5. ${ }^{13} \mathrm{C}-\mathrm{NMR}$ CP/MAS spectra of pure and grafted amylopectinrich stanch. 


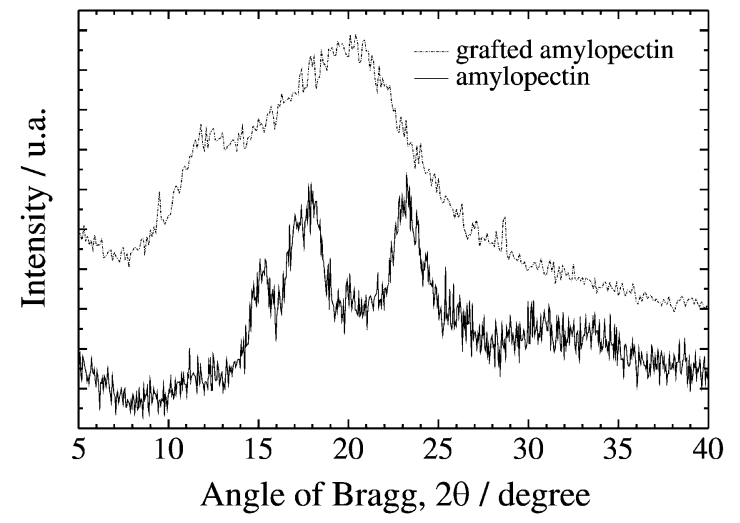

Figure 6. X-ray diffractograms of pure and grafted amylopectin-rich stanch.

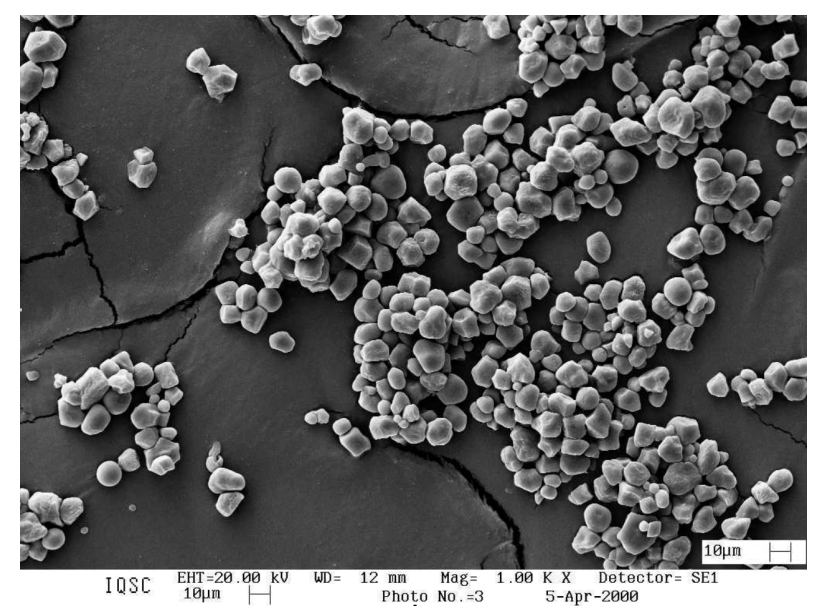

Figure 7. SEM micrograph of amylopectin-rich stanch grains deposited on carbon films (1000x).

result appears to corroborates the results obtained by scanning electronic microscopy. The amylopectin micrographs (Fig. 7) show a granular structure, with average grain diameter ranging from 7 to $15 \mu \mathrm{m}$. The films of grafted amylopectin appear without grains, although there are some lighter domains (Fig. 8), which may be due to the larger concentration of film in the sample.

Figure 9 shows the DSC curves of the pure and grafted amylopectins. It can be observed, that the glass transition temperature $\left(\mathrm{Tg}\right.$ ) for pure amylopectin is about $50^{\circ} \mathrm{C}$ (usual for this kind of amylopectin sample $e^{17,18}$ ) and after grafting reaction this $\mathrm{Tg}$ value drop to $-11^{\circ} \mathrm{C}$. This lower than room temperature $\mathrm{Tg}$ in grafted samples is a highly relevant factor for the potential application of this material as solid electrolytes, since low $\mathrm{Tg}$ allows for greater chain mobility and, hence, improve solvation and ion conduction.

\section{Conclusion}

Amylopectin-rich starch was characterized and submitted to a grafting reaction with toluene poly(propylene oxide) diisocyanate with the purpose of producing a new starting material for the preparation of solid polymeric

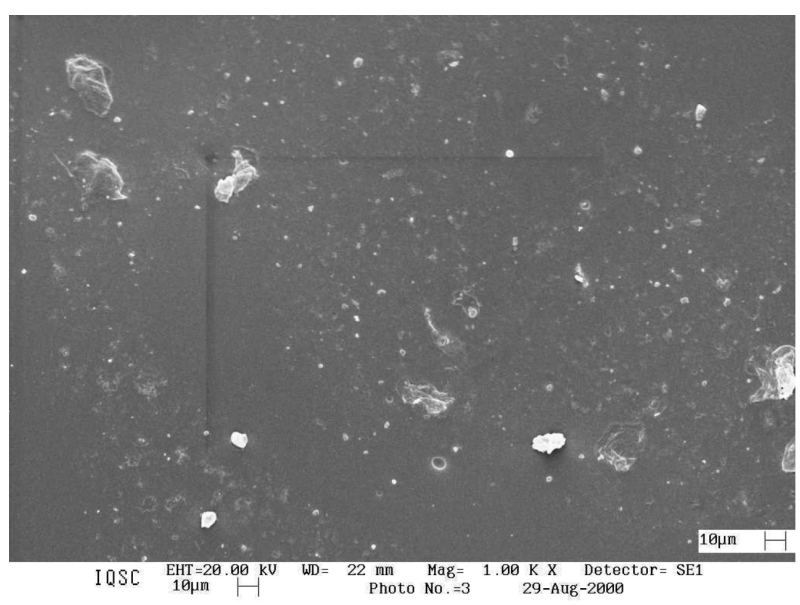

Figure 8. SEM micrograph of amylopectin-rich stanch grafted with toluene poly(propylene oxide) diisocyanate (1000x).

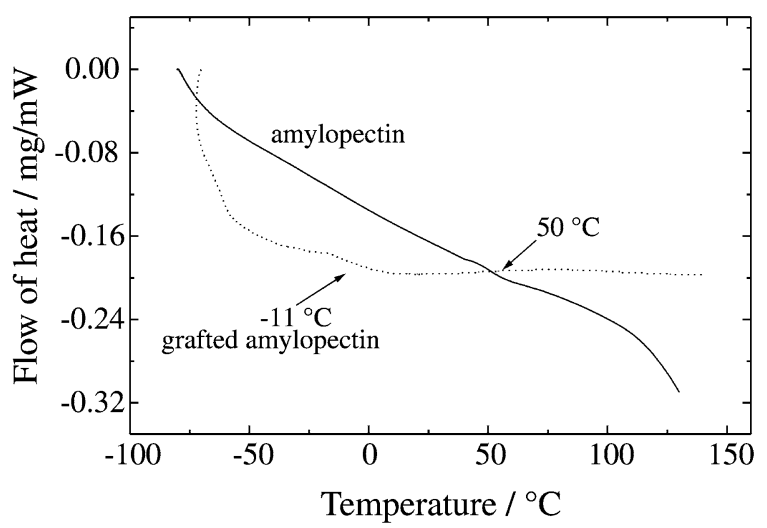

Figure 9. DSC curves of pure and amylopectin-rich stanch grafted with toluene poly(propylene oxide) diisocyanate.

electrolytes. After the grafting reaction, the FTIR analysis revealed appearance of band attributed to the $\mathrm{NH}$ bond and the disappearance of diisocyanate NCO bands. The RMN spectra showed new peaks, which were attributed to the poly(propylene oxide) methyl groups, and to aromatic toluene ring peaks indicative of the occurrence of a grafting reaction. The SEM micrographs of pure and grafted amylopectin samples showed that the characteristic crystalline granules of starch disappear after the grafting reaction. Thermal analysis reveal also that the $\mathrm{Tg}$ values of the pure samples drop from $50{ }^{\circ} \mathrm{C}$ to $-11{ }^{\circ} \mathrm{C}$ after grafting reaction. These results show that this kind of material is a good potential candidate for solid polymeric electrolyte applications.

\section{Acknowledgments}

The authors thank FAPESP for the financial support of this research work. The contributions of starch from Corn Products Ingredientes Industriais Ltda. and of diisocyanate from Resibras are also gratefully acknowledged. Special 
thanks are due to Prof. Dr. A. Aprigio S. Curvelo for his highly relevant scientific discussions.

\section{References}

1. Regiani, A.M.; Pawlicka, A.; Curvelo, A.A.S.; Gandini, A.; Le Nest, J.F. Polímeros: Ciência e Tecnologia, n. 3, p. 45, 1999.

2. Armand, M.B.; Chabagno, J.M.; Duclot, M.J. Fast Ion Transport in Solids, eds. Vashishta, P; Mundy, J.N.; Shenoy, G. K. Amsterdam, North-Holland, p. 131, 1979.

3. Carvalho, L.M.; Guégan, P.; Cheradame, H.; Gomes, A.S. European Polymer Journal, v. 36, p. 401, 2000.

4. Tambelli, C.E.; Donoso, J.P.; Magon, C.J.; Ângelo, A.C.D.; Florentino, A.O.; Saeki, M.J. Solid State Ionics, v. 136, p. 243, 2000.

5.Zoppi, R.A.; Fonseca, C.M.N.P.; De Paoli, M.A.; Nunes, S.P. Solid State Ionics, v. 91, p. 123, 1996.

6.Zoppi, R.A.; Fonseca, C.M.N.P.; De Paoli, M.A.; Nunes, S.P. Acta Polymer., v. 48, p. 193, 1997.

7. Munro, B.; Krämer, S.; Zapp, P.; Krug, H.; Schmidt, H. SPIE, v. 3136, p. 470, 1997.

8. Dahmouche, K.; Atik, M.; Mello, N.C.; Bonagamba, T.; Panepucci, H.; Judeinstein, P.; Aegerter, M.A. Solar Energy Materials and Solar Cells, v. 54, p. 1, 1998.
9. Schoenenberger, C.; Le Nest, J.F.; Gandini, A. Electrochimica Acta, v. 40, p. 2281, 1995.

10. Velazquez M.P; Le Nest, J.F.; Gandini, A. Electrochimica Acta, v. 43, p. 1275, 1998.

11. Galliard, T. Starch: Properties and potential, Critical Reports on applied chemistry, Galliard, T., ed. John Wiley \& Sons, v. 13, p. 1, 1987.

12. Lorcks, J. Polymer Degradation and Stabability, v. 59, p. 245, 1998.

13. Regiani, A M.; Tambelli, C.E.; Pawlicka, A; Curvelo, A.A.S.; Gandini, A.; Lenest, J.F.; Donoso, J.P. Polymer International, v. 49, p. 960, 2000.

14. Athawale, V.D.; Lele, V. Carbohydrate Polymers, v. 41, p. 407, 2000.

15. Silverstein, R.M.; Bassler, C.G.; Morril, T.C. Identificação Espectrométrica de Compostos Orgânicos, $5^{\circ}$ edição, ed. Guanabara Koogan S. A., Rio de Janeiro, 1991.

16. van Soest, J.J.G.; Vliegenthart, F.G.J. TIBTECH, v. 15, p. 208, 1997.

17. Rindlav, A.; Hulleman, S.H.D.; Gatenholm, P. Carbohydrate Polymers, v. 34, p. 25, 1997.

18. Song, Y.; Jane, J. Carbohydrate Polymers, v. 41, p.365, 2000.

FAPESP helped in meeting the publication costs of this article 